\title{
Origens do realismo na teoria estética marxista do entreguerras
}

\author{
Marcos Rogério Cordeiro* \\ Alysson Quirino Siffert**
}

\begin{abstract}
Resumo
O objetivo deste artigo é apontar como percursos intelectuais distintos, na primeira metade do século $\mathrm{XX}$, levaram importantes nomes da teoria estética a um método marxista comum, incorporado às discussões literárias no período entreguerras. Nesse sentido, busca-se demonstrar como o período formativo mais idealista do círculo de Bakhtin e dos formalistas russos, bem como o de György Lukács e de Walter Benjamin, não impediram que suas obras culminassem numa noção mais dialética e historicizada sobre o conceito estético de "realismo". Assim, buscaremos enfatizar que a ideia de uma condensação não mecânica da realidade na forma artística é a baliza central de todos esses autores, e é o que, em última instância, mais unifica que aparta suas distintas teorias.
\end{abstract}

Palavras-chave: Realismo. Marxismo. Bakhtin. Lukács. Benjamin.

O conceito de realismo talvez seja mais debatido no campo da literatura e da estética devido ao seu caráter polissêmico, comportando significados até opostos a depender da tendência teórica que o utiliza. Mesmo no interior de uma tradição crítica mais ou menos coerente e delimitada, como a marxista do período entre as duas guerras mundiais, foram traçados diversos caminhos em torno de uma noção dialética de realismo. Tais diferenças não se devem apenas a uma questão de concepções estéticas distintas, ou de mera semântica conceitual; antes, derivam de uma característica própria da realidade: não apenas seus conteúdos e formas são heterogêneos e variáveis no tempo e no espaço, como também são bem distintos os possíveis modos de representá-los e de teorizar sobre essa representação. Reconhecer tal polissemia parece fundamental para ressaltarmos o oposto, isto é, aquelas linhas de força que, a partir de percursos intelectuais distintos, vão

* Universidade Federal de Minas Gerais (UFMG). Doutorado em Letras pela Universidade Federal do Rio de Janeiro.

** Universidade Federal de Minas Gerais (UFMG). Mestrando do curso de Pós-graduação em Estudos Literários da Universidade Federal de Minas Gerais. 
unificando o fundamento teórico das mais refinadas perspectivas marxistas do referido período. A ênfase analítica dessa identidade da não-identidade é o maior objetivo do presente artigo.

Podemos dizer que o realismo se colocou como uma questão essencial para a crítica marxista, sobretudo por se tratar de um procedimento compositivo cujas implicações ultrapassam o campo delimitado da arte, indo mais fundo no tecido social. Assim, embora desenvolvido como linguagem e mantendo uma inegável especificidade estética, o realismo pode ser visto como um conjunto de técnicas que sempre possui sua razão de ser, em última instância, na realidade histórico-social, que lhe é prévia, mas que o realismo assimila formalmente e ajuda a compreender. Com isso, estimula-se a emancipação da consciência humana mediante o crivo crítico, algo crucial para a superação dos entraves da própria realidade. Esse é um ponto de concordância entre os principais autores marxistas que lançaram os alicerces de suas obras entre 1914 e 1945.

Entre a fatura artística e a complexa ordem de questões que exerce sobre ela seu poder de configuração (questões que derivam da realidade concreta), existe um campo de mediações cuja lógica é incorporada e estilizada na obra de arte. Tais mediações são sintetizadas e se manifestam na forma, que, aqui, portanto, não é entendida como resultado arbitrário da criação individual ou subjetiva, nem como técnica de experimentação, mas como um substrato objetivo que é indissociável do conteúdo que precede e condiciona o trabalho artístico e a fatura artística propriamente dita.

Embora apresentem concepções diferentes entre si, os autores que indicamos possuem em comum uma recepção viva e inteligente do marxismo, ou seja, enfrentam as dificuldades teóricas da relação de forma e conteúdo sem cair em esquemas fixos ou preconcebidos, sempre procurando reconhecer o vínculo de realismo e realidade em suas estruturas mais profundas, o que também os leva a frisar a qualidade especificamente artística das obras de arte. Um filósofo um pouco posterior, Adorno, cujas conclusões estéticas do pós-guerra dialogam intimamente com o percurso de amadurecimento que será tratado aqui, apresenta essa questão nos seguintes termos:

Contra a divisão pedante entre forma e conteúdo, é preciso insistir na sua unidade e, contra a concepção sentimental da sua indiferença na obra de arte, insistir no fato de sua diferença subsistir ao mesmo tempo na mediação. [Assim] quanto mais profundamente o conteúdo 
experimentado se transforma, até deixar de ser reconhecível, em categoria formal, tanto menos os materiais não sublimados são comensuráveis ao conteúdo das obras de arte. Tudo o que aparece na obra de arte é virtualmente conteúdo tal como forma, ao passo que esta permanece, no entanto, o meio de definição do que aparece e o conteúdo permanece o que se define a si mesmo. (ADORNO, 1988, p. 167-169).

Em outras palavras, também de um crítico marxista experiente no debate sobre a dialética entre literatura e realidade, "o social na obra está na forma. Não que os conteúdos não sejam sociais, mas a forma, ao trabalhá-los e organizá-los, ou ser infletida por eles, configura algo de mais geral, análogo à precedência da sociedade sobre seus conteúdos separados." (SCHWARZ, 2012, p. 288).

Nosso interesse, portanto, será discutir aqui esse imperativo teórico - a condensação formal da realidade na obra de arte - segundo alguns influentes pensadores cuja formação crítica e assimilação do marxismo ocorreu no aludido período entreguerras. Como veremos, essa questão não nasce pronta e, sim, amadurece aos poucos, impulsionada pelo revisionismo conceitual e pela experiência concreta diante do movimento histórico. Não obstante, em vez de arriscarmos um panorama exaustivo, preferimos focalizar dois importantes grupos: por um lado, os teóricos ligados à tradição cultural do leste europeu, com destaque para o grupo formalista e o círculo bakhtiniano, e, por outro, dois intelectuais da Europa central, ligados às correntes filosóficas e artísticas da modernidade: György Lukács e Walter Benjamin. Voltados para a literatura, esses autores - cada um a seu modo - entendem a forma como sistema mediador do conjunto orgânico da obra literária, um sistema dialético que, ao ser formalizado artisticamente, reflete algo que já existia no mundo empírico. A noção de realismo neste marxismo heterodoxo não se resume a um deciframento sociológico de relações entre literatura e realidade social; antes, gira em torno de um esforço de elucidação estética que é simultânea à compreensão da realidade, cuja configuração na obra ocorre como imanência. Consequentemente, ao recuperar o significado historicizado da forma artística, a perspectiva realista insiste na relevância da literatura para o mundo contemporâneo, pois, do contrário, privado da perspectiva realista, o dito mundo contemporâneo aumenta o risco de ser dominado pelo conformismo político e intelectual e de cair nas trevas do irracionalismo, levando a literatura consigo, que assim perde sua verdadeira função emancipatória. 
Pois bem: podemos dizer que o formalismo russo dá início à teoria da literatura em seu sentido moderno, isto é, como um campo dotado de conceitos e metodologia próprios e não como parte de uma teoria geral da arte ou da cultura. Isto não quer dizer que não houvesse reflexão crítica antes, mas não havia uma sistematização de princípios, nem uma delimitação clara do objeto ou um conjunto de categorias que especificasse o campo literário. A noção de poiésis dos antigos incluía, além do que hoje chamamos literatura, também o drama, a música, a dança, a arquitetura e a escultura. Desde então, até o romantismo mais ou menos, quando aparecem os primeiros sinais desse sentido moderno a que nos referimos, a apreciação e a reflexão a respeito da literatura tendiam a vê-la através de formulações abstratas, elaboradas a partir de ideias gerais sobre o tempo, a natureza e o espírito humano. Os teóricos do formalismo, por sua vez, procuraram identificar, analisar e interpretar o que havia de singular na arte literária, a "literariedade" (EIKHENBAUM, 1973, p. 3-38). Temos aqui um salto qualitativo, melhor avaliado quando entendido à luz de certas condições históricas que os próprios teóricos reconheceram e incorporaram.

Alguns fatores históricos foram cruciais para essa mudança de qualidade. Entre eles, uma influência pontual, mas muito marcante, da escola de Genebra, especialmente de Ferdinand Saussure, que introduziu uma série de noções que irão nortear o formalismo russo, principalmente sua concepção de signo como sistema autorregulado, plenamente expressivo e coerente em si mesmo. Para Saussure, o signo se apresenta como um constructo da linguagem, regido por leis estabelecidas pela própria linguagem. Os formalistas partiram daí para definir a linguagem literária como tal, na tentativa de reconhecer elementos funcionais que delimitam aquilo que a especifica. Outro fator que vai concorrer para o aporte teórico do formalismo é a proliferação de correntes de vanguarda, como o futurismo: em vez de entusiasmo pelas conquistas da modernização técnica, como ocorreu com o futurismo italiano, na Rússia ele assumiu uma postura seletiva, apropriando e rejeitando aspectos pontuais da dita modernização. Do ponto de vista ideológico, acentuadamente historicizado, também se encontram diferenças: enquanto o futurismo italiano propagava o fascismo, o russo se identificava com o comunismo já incorporado ao país. Quanto às questões de arte, investiram numa elaboração formal complexa, desenvolvida na arquitetura, na música, no teatro e no cinema. No que diz respeito à literatura em particular, insurgiu-se contra o simbolismo e procurou desenvolver uma linguagem formal baseada em princípios construtivistas. Em outras palavras, podemos dizer que a poética de vanguarda 
na Rússia consistia na transfiguração contínua de ideia em forma e de forma em ideia, o que lhe garantia uma acentuada autorreferencialidade. Isso estimulou a renovação teórica dos formalistas, levando-os à procura de novos parâmetros de análise. Os que existiam, norteados, como se disse, por princípios teóricos gerais, não eram capazes de identificar o específico artístico nessas obras e chegavam mesmo a pôr em dúvida o seu caráter estético. Os formalistas, no entanto, viam aqui a necessidade de desautomatizar a percepção da forma artística.

Mais um fator decisivo para o salto formalista aparece na recepção teórica do marxismo, suficientemente amadurecido e disseminado na Rússia da época (não se pode esquecer que as vanguardas e a escola formalista surgiram entre duas revoluções, a de 1905 e a de 1917). Esses movimentos coetâneos se correspondem e se esclarecem reciprocamente, pois o marxismo circulava nos meios artísticos de vanguarda, dando insumo a uma visão materialista a respeito da arte sob o domínio do capital: os vanguardistas reconheciam com clareza que o estado estabilizado da arte era uma configuração dos ideais burgueses dominantes e não estavam inocentes para o fato de que atacar a linguagem artística hegemônica era atacar a sociedade tal como se encontrava estruturada - daí a ideia de "chocar a burguesia". Esses dados devem ser considerados segundo a força do conjunto: revolução artística e revolução social se equivalem neste momento e desfazer esse vínculo é perder um pouco do esclarecimento de ambas. Neste sentido, o marxismo altera e refaz o campo teórico formalista na medida em que começa a ser incorporado pelos formalistas como parte do método de análise.

Uma breve digressão demonstra isso melhor. Os formalistas firmaram a sua teoria em contraposição às diretrizes dominantes na época, representadas pelas críticas biográfica, psicológica, filosófica e historicista. A biográfica pautava-se na vida dos escritores para explicar os fatos literários; a psicológica procurava as motivações inconscientes; a filosófica introduzia a obra particular em um contexto geral da história da cultura, o que acabava obscurecendo seu caráter específico; e a historicista limitava-se a um cotejamento de texto e contexto puxado para o documental. Apesar das diferenças, essas correntes em comum partem do conteúdo manifesto para explicar a obra, deixando em segundo plano ou mesmo desconsiderando a particularidade da forma. Em contrapartida, os teóricos russos se voltam para ela advertindo, porém, que a forma não é algo arbitrário, não é impalpável, mas se manifesta de maneira concreta. (EIKHENBAUM, 1973, p. 1314). 
Em pouco tempo as premissas formalistas foram se aprofundando em questões de ordem extraliterária, incorporando de maneira seletiva e funcional as premissas do realismo - mesmo sem chamar pelo nome - às suas teses fundamentais. $\mathrm{O}$ curso dos fatos, entretanto, acirrou as bases teóricas dessa aproximação na medida em que o marxismo foi sendo absorvido pelo sectarismo ideológico do momento. Ironicamente, o crescente interesse pelas formas histórico-sociais coincide com o início da política cultural stalinista, que fez tábula rasa da complexidade das teses dialéticas e imprimiu nelas uma rigidez que não possuíam. Sua consequência imediata foi a criação de um padrão intelectual e de gosto que fez surgir o realismo socialista, criando uma polarização entre ele e o esteticismo, que passou a ser identificado com o gosto artístico burguês, bem como com seu projeto intelectual. Essa polarização serviu de justificativa para a repressão aos representantes e às ideias do grupo formalista, que se dissolveu.

O chamado círculo de Bakhtin se desenvolveu em diálogo com essa polarização estético-ideológica e se alimentou de suas contradições. Como mostra $\mathbf{O}$ método formal dos estudos literários, de Medvedev, sem apresentar uma definição clara de síntese, o autor oscila entre a crítica ao formalismo ou ao realismo socialista ${ }^{1}$. Havia uma percepção clara de que o realismo socialista, embora engendrado no interior da tradição marxista, não respondia por ela e estava longe de desenvolver com propriedade o que o termo "realismo" representava. Na verdade, Medvedev destaca o contrassenso do realismo socialista atender às exigências do marxismo e do realismo ao mesmo tempo porque ele abriu mão de um de seus imperativos, a dialética. A ausência de uma perspectiva dialética levou o realismo socialista a uma "concepção simplista que via na forma uma espécie de anexo ornamental ou decorativo do conteúdo, apêndice carente de seu próprio sentido ideológico" (MEDVEDEV; BAKHTIN, 1994, p. 100). Ciente da estrutura dinâmica que é a obra literária, Medvedev reconhece que isso se deve ao fato de que ela representa, em sua imanência, a formalização da realidade, enfatizando a transformação de externo em interno (MEDVEDEV; BAKHTIN, 1994, p. 127). Embora o termo não apareça com ênfase, o realismo é o método crítico (“dialético e ágil") que permite que se entenda a constituição artística em sua relação de causalidade específica com a realidade.

1 Adotamos o ponto de vista de que trata de autores individualizados e independentes que, no entanto, formam um grupo coeso, com propostas orgânicas e em relação. Nas referências bibliográficas, seguimos a orientação das fichas catalográficas das edições consultadas, que, via de regra, sobrepõem a autoria; porém, alteramos a sequência autoral, dando assim mais destaque aos autores que efetivamente escreveram o trecho, e não a Bakhtin, que em geral aparece em destaque por uma questão editorial ou de ordem alfabética. 
Tais premissas reaparecem no trabalho de Volochinov sobre o signo em geral e o literário em particular. Marxismo e filosofia da linguagem traz uma série de considerações a respeito do constructo artístico como dispositivo semiológico da realidade transfigurada. Ressalve-se que os conceitos-chave empregados (linguagem, signo e semiologia) representam o substrato objetivo da forma, afiançando o dado realista mesmo sem se dirigir diretamente à realidade. Isso se deve ao fato de que o signo é entendido como a formalização de uma "relação recíproca entre infraestrutura e superestrutura" (VOLOCHINOV; BAKHTIN, 1997, p. 38). Nas alegações contrárias às teses "psicológicas" e "idealistas", o autor afirma que "o signo é um fenômeno do mundo exterior, [...] que reflete e refrata outra realidade" (VOLOCHINOV; BAKHTIN, 1997, p. 31-33), demonstrando que é por intermédio dele que a dialética interna e externamente se configura. Seu esforço se concentra na superação teórica dos embates polarizados entre esteticismo e realismo socialista, construindo uma via de acesso inteligente do marxismo como método de análise da literatura, partindo sempre "da linguagem concebida como filosofia do signo ideológico" (VOLOCHINOV; BAKHTIN, 1997, p. 38). O signo é visto como dispositivo realista, não porque descreve diretamente a realidade, mas porque formaliza os processos objetivos mais essenciais dessa realidade. Em outras palavras, o realismo não está tanto na matéria formalizada, mas na forma propriamente dita, pois nela se estrutura a mediação entre o que é menos óbvio na realidade (suas estruturas profundas) com o que é mais elaborado na literatura (a linguagem).

A discussão teórica desenvolvida nesses livros é incorporada ao método de análise de Problemas da poética de Dostoiévski, de Bakhtin, permitindo que se descubra uma forma de composição peculiar na obra do romancista russo. Segundo Bakhtin, o gênero romance se caracteriza pela mistura de fontes e a multiplicidade de estilos, mas, no caso de Dostoiévski, ele vê o proveito dessa forma levado a um ponto extremo de invenção, não encontrada no romance russo ou europeu. Sua análise adota uma perspectiva materialista para descobrir, no romance de Dostoievski, um realismo próprio. Análise dos caracteres, que representam o ponto alto para a fortuna crítica, para Bakhtin possui uma conotação não subjetivista. Para ele, é a formalização "precisa do psicologismo como realista-objetiva da coletividade contraditórias das psiques" (BAKHTIN, 1997, p. 38). A realidade dinâmica da sociedade penetra as camadas mais profundas do romance, criando uma espécie de mundivisão das diversas consciências dramatizadas das personagens sob 
as condições formais da "polifonia". Cabe aqui uma observação: a leitura posterior que se fez desse conceito desistoricizou o ponto de vista crítico de Bakhtin, distorcendo o viés realista que sua análise procurou especificar, enfrentando as armadilhas de um estilo rebuscado, como o do escritor russo, para alcançar o seu significado histórico preciso. Voltando à tese propriamente dita, o autor não deixa dúvidas: a estrutura e a forma do romance polifônico se devem menos à consciência conturbada do autor ou às particularidades linguageiras do gênero romance do que às condições da realidade histórica.

O romance polifônico só pode realizar-se na época capitalista. Além do mais, ele encontrou terreno mais propício justamente na Rússia, onde o capitalismo avançara de maneira quase desastrosa e deixara incólume a diversidade de mundos e grupos sociais, que não afrouxaram, como no Ocidente, seu isolamento individual no processo de avanço gradual do capitalismo. Aqui, a essência contraditória da vida social em formação, essência essa que não cabe nos limites da consciência monológica segura e calmamente contemplativa, devia manifestar-se de modo sobremaneira marcante, enquanto deveria ser especialmente plena e patente a individualidade dos mundos que haviam rompido o equilíbrio ideológico e se chocavam entre si. Criavam-se, com isto, as premissas objetivas da multiplanaridade essencial e da multiplicidade de vozes do romance polifônico. (BAKHTIN, 1997, p. 19).

Como se vê, entre realismo e realidade constitui-se um campo de mediações já formado, cuja lógica compete à crítica descobrir. A análise permite perceber a realidade em suas determinações menos conhecidas, porque ela se encontra sedimentada na forma. A teoria literária contemporânea desvirtua as premissas desse debate ao defender a ideia de que a realidade na literatura é uma convenção, que se trata de uma construção discursiva, enquanto a realidade ela mesma é definida como algo amorfo, uma aparência de forças cegas trabalhando por si mesmas, em desagregação. O marxismo não vê assim, reconhecendo, na realidade, uma forma complexa. Em uma definição sucinta, encontramos o fundamento teórico desse ponto de vista.

O concreto é concreto porque é a síntese de múltiplas determinações, portanto, unidade da diversidade. Por essa razão, o concreto aparece no pensamento como processo da síntese, como resultado, não como ponto de partida, não obstante seja o ponto de partida efetivo e, em consequência, também o ponto de partida da intuição e da representação. [...] Por isso, a sociedade de modo algum só começa 
ali onde o discurso é sobre ela enquanto tal. (MARX, 2011, p. 5459).

O realismo, enquanto linguagem literária, configuração estética, responde pela formalização das múltiplas determinações, sendo, por isso, ele mesmo uma determinação; enquanto teoria crítica, o realismo permite que se reconheça e especifique o sentido dessas determinações, transfiguradas para o âmbito da arte. Essas ideias tiveram desenvolvimento paralelo e foram mais aprofundadas, como se verá a seguir.

Incitados por uma época de profundos abalos e rupturas, que teve a Primeira Guerra Mundial e a Revolução Russa de 1917 como marcos decisivos, alguns pensadores e artistas viram no marxismo uma resposta para as graves catástrofes emanadas das lutas imperialistas, superando com isso uma anterior perspectiva, mais fatalista, que tomava como algo quase insolúvel o aparente pulo da humanidade no abismo. À semelhança do próprio Marx, tais intelectuais, em suas fases formativas, tiveram grande contato com sistemas de pensamento gerados no auge da cultura burguesa, como a filosofia clássica alemã que vai de Kant a Hegel; e depois, ao irem assimilando as premissas da dialética, conseguiram transitar de noções mais subjetivistas e idealistas para outras mais objetivas e materialistas, isto é, mais realistas. Esse é o caso, sobretudo, de György Lukács e Walter Benjamin, que, ao lado de outros importantes nomes (como Bertold Brecht e Ernest Bloch), desenvolveriam durante os anos entre as duas grandes guerras um riquíssimo debate estético, que até hoje tem muito a ensinar sobre os problemas da análise e do fazer artístico. Nos limites deste artigo, iremos apenas sugerir o que há de essencialmente convergente entre as visões de Lukács e Benjamin, que se aproximam, neste sentido mais essencial, das já aludidas conclusões de Bahktin e de seu círculo - não obstante as potenciais ou abertas divergências entre tais teorias, que aqui não iremos explorar mais a fundo.

O problema da forma como mediação artística aparece cedo em todos esses autores, ainda em fases de juventude ligadas a premissas idealistas ou metafísicas, isto é, até mesmo antes da assimilação do marxismo. No caso do jovem húngaro György Lukács, suas primeiras obras em alemão são condicionadas por uma epistemologia neokantiana; mas seus escritos se destacaram como algo autenticamente novo, causando um imediato impacto em alguns dos principais círculos intelectuais europeus, como o liderado por Max Weber. Desde os juvenis Evolução histórica do drama moderno e A alma e as formas, as obras de Lukács 
tendem a incorporar algo do movimento histórico em suas teorizações e críticas, embora o idealismo kantiano inicial imponha um tal acento subjetivista que isso o leva a apresentar a forma como uma delimitação última de apreensão do mundo, de maneira que o próprio mundo se desmancha quando não conformado num construto subjetivo. O pensamento e a arte - como poesia, ensaio, historiografia etc. - converteriam subjetivamente essa forma apriorística, já dada na estrutura mental, em uma concepção a partir da qual seria possível entrever o destino desse mundo. Através da forma, o pensamento poderia se impor, organizando tudo ao realizar associações e erigir teses, assim compreendendo aquilo que na empiria é caótico, anárquico e sem sentido imanente. Note-se aqui o duplo direcionamento do raciocínio do jovem Lukács no que se refere aos propósitos aqui discutidos: a forma confere rigor, garante racionalidade e se manifesta por meio da organização de todos os elementos constitutivos, não deixando que nada se perca de si ou que perca o significado mais elevado, menos óbvio; ao mesmo tempo, ela é algo que delimita o concreto, que, sem ela, não se mostra capaz de sustentar o seu próprio significado. Assim, a realidade histórica, se por um lado se mostra essencial para a teoria do conhecimento defendida pelo jovem Lukács, por outro lado não possui força própria de estruturação, cabendo essa função à forma.

Tal postura, que será bastante criticada pelo próprio Lukács maduro, começa a mudar nos próprios ensaios de A Alma e as formas, mas, de modo mais significativo, em A teoria do romance, obra que, avançando o percurso da filosofia clássica alemã, se beneficia decisivamente de uma concepção mais dialética e objetiva, derivada de Hegel. Uma das contribuições centrais deste livro, também de imenso impacto na intelectualidade europeia, foi criar uma teoria geral do romance com o intuito de integrá-lo num sistema de formas estéticas. Até então, a maioria dos estudos procurava comprovar que o romance não era um gênero novo, mas uma reconfiguração de um gênero antigo, a epopeia. Herdando o pensamento hegeliano, Lukács reafirma a singularidade do romance enquanto gênero e relaciona isso com a formação de uma sociedade particular que ia se estruturando, a moderna sociedade burguesa. As sociedades tradicionais, não obstante as contradições e assimetrias que as caracterizam, produziram uma forma narrativa com alto grau de coesão, enquanto a sociedade moderna aprofundou essas contradições com tal intensidade que acarretou uma fratura no cerne da forma. Ou seja, a sociedade engendrada pelo capital acumulou as formas existentes e produziu outras, em sentido renovado de acordo com os novos tempos. Assim, 
para o Lukács de A teoria do romance, a forma do romance já aparece como uma mediação da forma histórica e as dissonâncias e rupturas próprias da forma romance são explicadas como propriedades históricas. Mas há nesse livro vários problemas e paradoxos derivados do idealismo objetivo. Numa passagem em que trata da relação forma-romance-história, por exemplo, nota-se que, embora seja apontada a dinâmica material da história, ainda se insiste em que ela se encontra submetida aos ditames da consciência: "A incapacidade de as ideias penetrarem no seio da realidade faz dessa última um descontínuo heterogêneo e, a partir dessa mesma proporção, cria para os elementos da realidade uma carência de vínculo." (LUKÁCS, 2000, p. 81). Mas essa tese idealista, de que a forma organiza o caos do mundo atribuindo-lhe significado, por conta da própria lógica dialética aparece invertida em outros pontos, sendo então explicada, de modo mais realista, como formalização de uma disposição prévia, concreta: "Todos os abismos e fissuras inerentes à situação histórica são incorporados à configuração [artística] e não podem ser encobertos por meios composicionais" (LUKÁCS, 2000, p. 60). O meio pelo qual essa formalização se efetiva no interior do romance altera a sua organização e ressignifica o estilo. Os dilemas de consciência do herói problemático (que aparece como um tipo pleno de variações e de significação histórica, não se limitando a uma individualidade excêntrica) e a configuração da ironia como dispositivo de reflexão em seu interior são exemplos dessa alteração na teoria geral de Lukács, tanto em sua teoria do conhecimento, quanto em sua teoria das formas. Assim, como pontua Carlos Nelson Coutinho e José Paulo Netto, no prefácio ao livro Arte e sociedade, uma coletânea de escritos estéticos de Lukács:

ainda que nos quadros do idealismo objetivo hegeliano, A teoria do romance propõe uma clara vinculação entre as formas estéticas e as épocas históricas, entre a arte e a sociedade, vinculação que se tornaria a principal preocupação estética do Lukács marxista. (LUKÁCS, COUTINHO, NETTO, 2009, p. 9).

Neste percurso, outro passo decisivo no pensamento de Lukács, já transitando de Hegel para Marx, se dá em História e consciência de classe. Nesta coletânea de artigos escritos entre 1919 e 1922, após a revolução russa de 1917 ter dado uma perspectiva revolucionária ao Lukács de trinta e poucos anos, as premissas idealistas e metafísicas começam a abandonar o seu sistema teórico, embora ainda, a essa altura, sobrevivendo lado a lado de suas primeiras teses marxistas, como deixa claro seu longo prefácio autocrítico de 1967. Apesar do próprio Lenin ter 
denunciado seu vanguardismo idealista e messiânico, denúncia que o maduro Lukács irá assinalar embaixo, esse livro será um dos mais influentes na filosofia do século XX, e é nele que Lukács assume pela primeira vez, de modo declarado, a preponderância da teoria marxista:

O marxismo ortodoxo não significa (...) um reconhecimento sem crítica dos resultados da investigação de Marx, não significa uma "fé" numa ou noutra tese, nem a exegese de um livro "sagrado". Em matéria de marxismo, a ortodoxia se refere antes e exclusivamente ao método. Ela implica a convicção científica de que, com o marxismo dialético, foi encontrado o método de investigação correto, que esse método só pode ser desenvolvido, aperfeiçoado e aprofundado no sentido dos seus fundadores, mas que todas as tentativas para supera-lo ou "aperfeiçoá-lo" conduziram somente á banalização, a fazer dele um ecletismo - e tinham necessariamente de conduzir a isso. (LUKÁCS, 2003, p. 65).

Com as lutas e guerras civis posteriores à revolução russa, em que Lukács chegou a ser ministro da cultura, comissário do povo e até general de ocasião na defesa da breve república soviética húngara de 1919, para depois se exilar na Alemanha e em Moscou, seus escritos filosóficos e estéticos sofreram por um tempo uma diminuição produtiva, embora o contato com a realidade prática tenha amadurecido sua reflexão de maneira imprescindível para a superação de suas últimas amarras idealistas. Não obstante, vale frisar que essa superação se deu no verdadeiro sentido da aufhebung hegeliana e marxista, isto é, como uma negação que leva a outro patamar, eliminando o que já estava morto ou defasado, mas preservando, simultaneamente, os acúmulos vivos e racionais. Por isso a obra madura de Lukács irá enfatizar inúmeras vezes, em franca oposição ao materialismo positivista oficial do stalinismo, o quanto a dialética materialista o leva a uma concepção mais reflexiva e crítica da realidade. De certa forma, estamos diante de duas concepções de realismo: o realismo socialista e o realismo crítico, que é a grande tese de Lukács. O próprio Lukács explica essa conversão de rota:

No Instituto Marx-Engels, conheci e trabalhei com o camarada Mikhail Lifchitz, com quem, no curso de longas e amistosas conversações, debati questões fundamentais do marxismo. O resultado ideal mais relevante deste processo de esclarecimento foi o reconhecimento da existência de uma estética marxista, autônoma e unitária. Esta afirmação, indiscutível nos dias de hoje, 
parecia a muitos marxistas, no início dos anos 1930, um paradoxo. (LUKÁCS, 2009, p. 25).

A partir dessas leituras decisivas, Lukács volta a produzir copiosamente, já agora no timbre de sua fase madura, que vai de 1933 a 1971, ano de seu falecimento. Com efeito, é da década de trinta em diante que se pode estudar a verdadeira obra Lukácsiana, isto é, aquela que já apresenta o último estágio de seu método filosófico, estético e crítico, despido das anteriores contradições idealistas. Isso é importante frisar, já que a hegemonia antirrealista posterior ao modernismo fez da juventude de Lukács sua fase mais citada e estudada, até com frequente omissão de sua obra madura, o que por si só já demonstra vícios e preconceitos idealistas por parte de intelectuais e professores do mundo inteiro. Ao contrário do que pregou tal moda acadêmica, o próprio Lukács considerava sua obra posterior a 1930 a mais válida e densa, a que continha as mais acertadas e concretas diretrizes teóricas. Foi somente em sua fase madura, por exemplo, que Lukács erigiu a defesa do realismo como a base mais essencial do seu pensamento estético e de sua atividade enquanto crítico literário. Nos ensaios filosóficos e críticos dessa fase, que irão depois culminar na grande Estética de 1960, Lukács julga o valor da arte com base em seu nível de realismo, ou seja, na capacidade da obra de captar e representar adequadamente as tendências e os tipos mais essenciais dos movimentos históricos decisivos. Nesse sentido, quanto mais decisivo for um momento histórico, em relação à humanidade, e quanto mais um artista é capaz de penetrar o que há de mais importante e vivo neste momento, mais ele estará sendo um grande realista, e, por conseguinte, um grande artista. É por isso que seu cânone do realismo é formado por nomes como Dante, Cervantes, Shakespeare, Goethe, Walter Scott, Balzac e Tolstói, além de Thomas Mann, que conseguiram sintetizar em suas obras, de modo autenticamente artístico, os progressos e lutas mais cruciais do gênero humano, e isso alcançando uma representatividade de proporções universais.

Assim, para Lukács, a marca da originalidade, em matéria de arte, não deriva de um incompreensível e abstrato dom natural, e sim reflete a própria originalidade do tempo histórico, que determinado artista conseguiu representar numa forma mais significativa, rica e profunda que a concebida pelos pares de sua época, comparados em escala global. Assim, a forma artística é mais original quando é a forma de um conteúdo histórico-social novo, isto é, quando consegue refletir esteticamente, com 
verdadeira maestria, as concretas alterações das estruturas da realidade:

De fato, se se considera - como já Hegel o fazia - a modificação histórica do conteúdo como base para a transformação da arte no que toca à forma, ao estilo, à composição, etc., é claro que no centro da criação artística deve estar precisamente este momento da transformação, do nascimento do novo, da morte do velho, das causas e das consequências das modificações estruturais da sociedade nas relações recíprocas entre os homens. A originalidade artística entendida como um voltar-se para a própria natureza e não para o que a arte produziu no passado no que diz respeito ao conteúdo e à forma - manifesta-se precisamente nesta importância que tem a descoberta e a determinação imediata do que de novo é produzido pelo desenvolvimento histórico-social. (...) Mas tão-somente na estética do marxismo esta antiguíssima questão recebeu um preciso sentido teórico: é original o artista que consegue captar seu justo conteúdo, em sua justa direção e em suas justas proporções, o que surge de substancialmente novo em sua época, o artista que é capaz de elaborar uma forma organicamente adequada ao novo conteúdo e por ele gerada como forma nova. (LUKÁCS, 1978, p. 192).

Tal concepção, aliada ao contínuo refinamento dos estudos históricos e da metodologia dialética, levará Lukács a analisar, numa longa obra, os momentos mais importantes do moderno avanço da sociedade burguesa, nisto comparando os autores mais significativos das principais tendências literárias de cada época. Nessa comparação valorativa, toma-se realismo como o maior princípio do julgamento artístico. Isso o leva a entrar numa aguda polêmica, em primeiro lugar, contra o naturalismo posterior a 1848, contra o irracionalismo romântico e, por fim, contra o vanguardismo modernista, que oscilaria entre o romantismo e o naturalismo de um modo cada vez mais irracional, mais superficial, e, assim, mais antirrealista. Se nisso Lukács parece, às vezes, ter sido duro em demasia em relação à literatura do século XX, por outro lado, o presente problema da irrelevância e banalidade artística da arte pós-moderna demonstra o quanto ele tinha razão em suas críticas a certas tendências propagadas pelo modernismo no mundo inteiro, como um subjetivismo empírico, irracionalista ou abstrato, que se tornou cada vez mais repetitivo e superficial. Nesse sentido, é preciso olhar com mais atenção os textos em que Lukács contrapõe $\mathrm{o}$ vanguardismo do século $\mathrm{XX}$ ao verdadeiro realismo, tanto pela profundidade teórica dessas polêmicas, quanto pelo simples fato da visível decadência da arte e da literatura posteriores a sua morte terem confirmado suas ressalvas contra a crescente hegemonia da teoria e da arte modernistas. Em outras palavras, já que o novo deve 
ser a chave do velho (conforme postula Marx), a crescente irrelevância estética e a superficialidade da hegemônica arte contemporânea, dita "pós-moderna", deveria levar a uma melhor aceitação e compreensão das passagens em que Lukács buscou combater a vanguarda modernista, como a seguinte:

Enquanto a literatura de vanguarda adota, em relação a alguns fenômenos do mundo moderno, uma atitude imediatamente não crítica, os melhores escritores realistas, na sua práxis literária (mas nem sempre nas suas exegeses críticas), despojam esses fenômenos do seu caráter imediato, de modo que possam tomar, em relação a eles, esse recuo de crítica sem o qual não poderia conceber-se uma verdadeira obra de arte. [...] Daquilo que não é mais do que um reflexo, necessariamente subjetivo, o escritor de vanguarda constrói o próprio real; pretendendo erigi-lo em objetividade constituinte, apenas nos dá uma imagem deformada da realidade total. O realista, pelo contrário, sendo capaz de criticar e de ultrapassar os dados imediatos, tende a situar o fenômeno necessário do nosso tempo no seu verdadeiro lugar, num conjunto total e coerente, no lugar que lhe pertence em razão da sua essência objetiva. (LUKÁCS, 1991, 82-84).

Por outro lado, a própria teoria do realismo de Lukács, uma vez bem assimilada, poderia servir como um potente instrumento de interpretação dos dispositivos especificamente artísticos, presentes em obras de valor, inclusive naquelas filiadas a escolas modernistas. Pois mesmo em certas obras de vanguarda há momentos que superam as limitações apontadas por Lukács, chegando a formalizações autenticamente realistas. Seja como for, o importante é destacar que o Lukács maduro sempre enfatiza, com eloquente cuidado, a especificidade propriamente estética das obras de arte, em contraposição, por um lado, ao modo científico ou filosófico de conhecer a realidade, e, por outro, ao modo empírico da cotidianidade e da conjuntura. Isso levará Lukács a conceber a categoria da particularidade como uma esfera mediadora própria das formas artísticas, por esta estar situada entre a singularidade da empiria cotidiana, no nível mais imediato, e a universalidade dos conceitos universais, no nível mais abstrato. A autêntica arte realista seria aquela cujo dínamo estruturador estaria situado nessa mediação do particular, sendo a particularidade a categoria específica do reflexo estético.

Vê-se que Lukács teve que dar um salto sobre ele mesmo, reinventar sua teoria das formas para alcançar uma noção bem meditada de realismo como conceito específico. Embora diferentes, a sua trajetória e a de Walter Benjamin se 
correspondem neste ponto; também ele teve que superar uma formação idealista inicial para chegar aos imperativos realistas. Em Benjamin, a postura metafísica se entranhou mais, ao ponto de ser mais facilmente assimilado ao gosto das teorias antirrealistas do pós-modernismo. O estilo metonímico e metafórico de seus escritos seduz esse público, carente da mesma formação dialética e materialista de seu autor. De fato, o termo realismo raramente aparece no vocabulário benjaminiano, muito menos em seu sentido teórico enfático; no entanto, sua análise se desenvolve em favor da compreensão realista da obra, analisada em relação com seu contexto. Na verdade, o realismo em Benjamin não só está no seu reconhecimento da representação como cifra da realidade, mas também no fato de que seus pressupostos teóricos se revelarem parte das mudanças estruturais que ocorreram no mundo e que determinaram sua própria vida.

Tentando restaurar esse trajeto em suas linhas gerais, lembremos que, após sua iniciação no ambiente intelectual da esquerda sionista, Benjamin escreve seu primeiro trabalho teórico de fôlego, $O$ conceito de crítica de arte no romantismo alemão, com evidentes dívidas com o idealismo crítico, especialmente Kant e Fichte. O trabalho apresenta uma noção de "crítica" como operação infinita de reflexão e autorreflexão conceitual na qual seu objeto é apurado multiperspectivamente: a consciência pensante se desidentifica de si mesma, volta-se sobre si mesma e antepõe-se a si mesma; neste movimento, põe e repõe o objeto, submetido a um intenso jogo de contradições conceituais. Trata-se de uma teoria do conhecimento sofisticada, empenhada na reflexão sobre cada passo, cada momento e determinação do próprio ato de refletir. Essa disposição constitui uma forma ("a reflexão é a reflexão de uma forma, demonstrando, desta maneira, a imediatez do conhecimento dado nela" BENJAMIN, 1993, p. 31), a qual delimitará a teoria de arte da primeira geração romântica na Alemanha, especialmente a sua noção de "crítica de arte". Como a forma é reflexão e autorreflexão dialeticamente posicionadas, a arte e a crítica se encontram implicadas numa dialética muito própria. “Crítica é, então, como que um experimento na obra de arte, através do qual a reflexão desta é despertada e ela é levada à consciência e ao conhecimento de si mesma”. (BENJAMIN, 1993, p. 74).

Como dissemos, a dialética exposta e defendida neste livro é a dialética idealista, gerada e desenvolvida pela consciência reflexiva. O objeto somente se firma nessa teoria do conhecimento enquanto objeto pensado, "medium-dereflexão". Quanto à forma propriamente dita, "nela é refletido aquilo que com 
certeza é a única coisa que pode refletir: o pensar" (BENJAMIN, 1993, p. 61). Reparem que, não obstante a tensão interior, o grau de organização e o poder de revelação, a forma é abstrata; a dialética presente é, por assim dizer, formada, mas limitada ao movimento do pensar em si mesmo, da linguagem em si mesma. Essa disposição sofre uma modificação na tese de habilitação sobre o barroco, um dos ensaios mais densos da teoria estética moderna. O livro traz alguns desafios que a banca não conseguiu vencer ou tenha sido mesmo ultrapassada por eles: a linguagem alusiva, cheia de imagens e associações livres, a estrutura assistemática, a afronta ao sistema platônico ou às categorias centrais do pensamento de Goethe etc., tudo se colocando fora dos padrões acadêmicos da época. Para o assunto que nos interessa, representou um passo importante, pois o conceito de forma começa a ser visto em sua relação efetiva com a realidade. Segundo Benjamin, as estruturas históricas penetram as camadas mais profundas da forma barroca, de onde emergem os significados político, ideológico e simbólico que condicionam sua organização e seu poder de representação (BENJAMIN, 1984, p. 239). Para Benjamin, o jogo de contradições típicos dessa forma não significa propriamente uma performance do pensamento e da linguagem, muito menos uma violação às leis "teleológicas" da história, mas, ao contrário, representa a sua estrutura formal: "Seu conteúdo, seu objeto mais autêntico é a própria vida histórica, como aquela época a concebia" (BENJAMIN, 1984, p. 86). Tome-se o caso de uma figura de linguagem que Benjamin elevou à categoria central de sua tese, a alegoria. À primeira vista, é a negação conceitual do realismo como método de configuração e como método de análise, mas é através dela que Benjamin vai elaborar a hipótese mais arrojada do livro no que se refere à configuração da forma histórica como forma artística. À maneira da dialética marxista, que via, numa formação histórica moderna, o acúmulo e a negação das formações anteriores, Benjamin vê na alegoria barroca a superação das alegorias medieval e renascentista, uma descoberta, como ele mesmo vai dizer, que "somente as variações históricas fazem aparecer" (BENJAMIN, 1984, p. 189). Quer dizer, no barroco, a forma alegórica é objetiva, e não um vezo estilístico, forma o que o movimento histórico constitui e revela. Tomada em perspectiva artística, a alegoria internaliza a história e a subsume, fazendo com que ela apareça como estilo. Há nisso clara operação realista no âmbito da forma: "Quando a história penetra o palco, ela o faz enquanto escrita" (BENJAMIN, 1984, p. 199). Essa síntese dialética, na qual uma proposição se encontra absorvida na forma de sua negação, aparece representada na caveira, 
em particular, ou em qualquer imagem da ruína (“As alegorias são no reino dos pensamentos o que são as ruínas no reino das coisas”, BENJAMIN, 1984, p. 200), pois a ruína, como a alegoria, oblitera o vínculo que liga o presente do sentido com a sua origem histórica. No símbolo, tais vínculos são reconhecíveis, mas na alegoria não, dando a impressão de que tudo é aleatório e não passa de um jogo livre de linguagem e significado. Veja-se a diferença e o avanço dessa noção materialista de dialética: nas imagens engendradas como forma barroca estão representadas as estruturas efetivas das relações sociais; as "antinomias do alegórico" passam a ser entendidas como abstração (em sentido dialético) ou estilização da forma histórica; as contradições do mundo histórico barroco - entre o ideal religioso e a contingência profana do capitalismo nascente - são internalizadas e transfiguradas artisticamente, ao ponto de se tornarem marca estilística.

Apesar dessa desenvoltura crítica no campo do materialismo, Origem do drama barroco alemão ainda conserva um pouco do idealismo anterior, principalmente na primeira parte, dedicada à teoria do conhecimento. Esse capítulo é muito importante para compreender a evolução do pensamento benjaminiano; nele vemos, na prática, as lições legadas pelo romantismo como a dialética antitética, a terminologia mística e a recusa da sistematização. Uma compreensão realista mais concatenada - sem referência ao termo, como dissemos antes aparece nos ensaios sobre a modernidade histórica através da obra de Baudelaire. Aqui Benjamin faz uma reconstituição minuciosa do II Império, explicando-o como estágio incipiente do capitalismo moderno: boêmia, revolução, prostituição, mercado, urbanização, dinheiro, ciência, filosofia, trabalho, memória, satanismo, flanerie, ópio, arquitetura, lesbianismo, literatura, mercadoria, melancolia etc., tudo aparece como forças integradas ao movimento histórico de afirmação desse modo de produção. As referências aos textos de Marx são sistemáticas, sem as quais o ensaio não teria como avançar, e sua influência é melhor manuseada no próprio discernimento sobre o estatuto inovador da poesia de Baudelaire: num mundo regido pela alienação compulsória, os traços da lírica são alterados em suas estruturas mais profundas. Não é que a poesia lírica não seja mais possível diante das imposições objetivas do capitalismo; o que ocorre é que ela vê sua forma substancialmente alterada sob as condições dessa nova realidade. Estamos diante de um dos pressupostos do realismo: as mudanças históricas, ao esgotarem um sistema, não rompem totalmente com eles; elas o transformam, mudam sua forma, com que ele continua existindo, mas com função e premissas diferentes: "Se as 
condições de receptividade de obras líricas se tornaram menos favoráveis, é natural supor que a poesia lírica, só excepcionalmente, mantém contato com a experiência do leitor. E isto poderia ser atribuído à mudança na estrutura dessa experiência" (BENJAMIN, 1989, p. 104). Temos aqui uma análise sucinta e precisa do contexto em sua dinamicidade específica: autor, obra e público inseridos num quadro histórico, atuando sobre ele e sendo alterados por ele. Para reconstruir esse cenário, Benjamin recorre a diários, poemas, verbetes, anúncios, notícias, romances, estudos historiográficos de todo tipo etc., não se limitando, porém, à coleta de dados e a apontamentos. Assim vemos mais claramente como a perspectiva crítica realista atua mesmo que seu nome não apareça, pois seu método, que consiste em concatenar grande diversidade de formas como totalidade, encontra o significado mais profundo, e menos óbvio, na realidade formada.

Para ficarmos com um bom exemplo: o processo de modernização capitalista e suas consequências (mobilidade demográfica, urbanização, choque de classes, diferenças ideológicas etc.) transformaram o sujeito, deu-lhe uma configuração subjetiva nova, alterando sua percepção de mundo e de si mesmo. Para usar uma expressão bem recorrente nesse caso, aparece um "sujeito fragmentado". Ficou comum elogiar essa figura, evidenciando nela a complexidade da constituição sensível e intelectual do homem moderno ou pós-moderno, tidos como mais afeitos às transformações cada vez mais rápidas do mundo e da percepção sobre ele, como se isso fosse resultado de um ato de vontade ou uma evolução natural da história. Benjamin, no entanto, realisticamente vê o contrário: a fragmentação do sujeito, em vez de degrau de sua emancipação ou liberdade, é sinal de sua reificação. Como se trata de um estudo de inspiração marxista, escolado no método que se desenvolve a partir do objeto, Benjamin colhe em Baudelaire a configuração literária dessa configuração histórica: "Quando Baudelaire fala de uma ebriedade religiosa da cidade grande, o sujeito, que permanece anônimo, bem poderia ser a mercadoria" (BENJAMIN, 1989, p. 53). O sujeito aqui referido não é uma construção de Baudelaire, mas um sujeito histórico, criado por uma sociedade específica. Quando a análise se volta para a fatura poética, esse sujeito histórico não some, ao contrário, ele reaparece transfigurado, mas objetivo. O sujeito lírico encarna o histórico, que delimita e constitui o primeiro: o sujeito que "fala" liricamente "é o próprio fetiche [da mercadoria]" (BENJAMIN, 1989, p. 52).

É preciso lembrar que Benjamin via em Baudelaire um poeta e um crítico dialéticos. Ao comentar as contradições cruas de seu pensamento, sua concepção 
de arte ou ideologia, ele ressalva que são as contradições próprias do momento histórico em que o poeta viveu: e se existe algo de inconciliável, frouxo ou grosseiro nessas contradições, isso reproduz o governo de Napoleão III, seu modelo de modernização e a luta de classes em curso. Trata-se, portanto, de uma análise no autêntico espírito do realismo, que enxerga a forma como a tradução estética de um determinado momento histórico, embora não de modo mecânico, e, sim, complexo, às vezes até muito sutil, escondido em detalhes poéticos que, à primeira vista, parecem estruturas autônomas, mas cujo traço vincado na história Walter Benjamin é capaz de revelar.

Portanto, apesar de existirem diferenças teóricas mais ou menos decisivas, que chegam a levar a interpretações até conflitantes sobre as concepções estéticas de cada autor que aqui abordamos, é fundamental enfatizar a diretriz comum que os unifica no mesmo campo marxista: a visão da arte como representação dos momentos essenciais da história, e, por conseguinte, da vida social. Nesse sentido, o realismo deve ser entendido como um método de figuração capaz de incorporar, na própria forma artística, as tendências, os tipos e as relações mais determinantes da realidade histórico-social - e não como um estilo de época datado e já superado. É assim que uma identidade realista subjaz aos distintos matizes teóricos dos marxistas que, neste artigo, estudamos de modo algo sumário, embora tentando destacar o que a maioria dos estudiosos de literatura não parece perceber.

\title{
Origins of realism in the marxist aesthetic theory of the interwar years
}

\begin{abstract}
The aim of this article is to point out how different intellectual paths throughout the first half of the twentieth century took important names of aesthetic theory to a common Marxist method, incorporated into literary discussions in the interwar period. In this sense, we seek to demonstrate how the more idealistic formative period of the Bakhtin Circle and the Russian formalists, as well of György Lukács and Walter Benjamin, did not prevent that these works culminated in a more dialectical and historicized notion about realism's aesthetic concept. Thus, we will seek to emphasize that the idea of a non- mechanical condensation of reality in artistic form is the central base of all these authors, and is what ultimately unifies rather than separates their different theories
\end{abstract}

Keywords: Realism. Marxism. Bakhtin. Lukács. Benjamin. 


\section{Referências}

ADORNO, Theodor W. Teoria estética. Lisboa: Ed. 70, 1988.

BAKHTIN, Mikhail. Problemas da poética de Dostoiévski. 2. ed. Rio de Janeiro: Forense Universitária, 1997.

BENJAMIN, Walter. Charles Baudelaire: um lírico no auge do capitalismo. São Paulo: Brasiliense, 1989.

BENJAMIN, Walter. O conceito de crítica de arte no romantismo alemão. São Paulo: Iluminuras; Edusp, 1993.

BENJAMIN, Walter. Origem do drama barroco alemão. São Paulo: Brasiliense, 1984.

EIKHENBAUM, Boris. A teoria do método formal. In: EIKHENBAUM, Boris et al. Teoria da literatura: formalistas russos. Porto Alegre: Globo, 1976. p. 3-38.

LUKÁCS, György; COUTINHO, Carlos Nelson; PAULO NETTO, Jose. Arte e sociedade: escritos estéticos 1932-1967. Rio de Janeiro: Editora UFRJ, 2009.

LUKÁCS, György. A alma e as formas. Tradução de Rainer Paulista. Belo Horizonte: Autêntica, 2015.

LUKÁCS, György. A teoria do romance: um ensaio histórico-filosófico sobre as formas da grande épica. São Paulo Duas Cidades; Ed.34, 2000.

LUKÁCS, György. História e consciência de classe: estudos sobre a dialética marxista. São Paulo: Martins Fontes, 2003.

LUKÁCS, György. Introdução a uma estética marxista: sobre a categoria da particularidade. Rio de Janeiro: Civilização Brasileira, 1978.

LUKÁCS, György; COUTINHO, Carlos Nelson. Realismo crítico hoje. 2.ed. Brasilia, D.F.: Thesaurus, 1991.

MARX, Karl. Grundrisse: Manuscritos econômicos de 1857-1858 - Esboço da crítica da economia política. São Paulo: Boitempo; Rio de Janeiro, EdUFRJ, 2011. MEDVEDEV, Pavel N.; BAKHTIN, Mikhail. El método formal en los estúdios literários - introducción crítica a una poética sociológica. Madrid: Alianza, 1994. SCHWARZ, Roberto. Martinha versus Lucrécia. São Paulo: Companhia das Letras, 2012.

VOLOCHINOV, Valentin N; BAKHTIN, Mikhail. Marxismo e filosofia da linguagem. São Paulo: Hucitec, 1997. 
Recebido em 02/05/2016.

Aceito em 08/09/2016. 